\title{
Illocutionary Speech Acts in the Discourse of Advertisements in Sindo Newspaper
}

\author{
Rafles Eko Putra ${ }^{1, *}$, Ermanto $^{1}$, Agustina $^{1}$, Kharisma Thahira ${ }^{1}$ \\ ${ }^{1}$ Indonesian Language Education Study Program, FBS Universitas Negeri Padang, Padang, West Sumatra 25131, \\ Indonesia \\ "Corresponding author. E-mail: raflesjobs@gmail.com
}

\begin{abstract}
This study aims to describe (1) the types of illocutionary speech acts used in the advertisement discourse in Sindo newspaper; (2) the story strategy contained in the advertisement discourse in Sindo newspaper; and (3) the background context, participants, objectives, action sequences, keys, tools, norms, types in the use of illocutionary speech acts contained in the advertisement discourse in Sindo newspaper. This research is qualitative research with a descriptive design. The data of this research were illocutionary speech acts in the discourse of Sindo's daily advertisements which were grouped based on the type, strategy, and context of the speech act. The results of this study were in the form of classification. The dominant illocutionary speech act found in the advertisement discourse in Sindo newspaper is directive speech acts. Then the dominant speech strategy in the advertisement discourse in Sindo newspaper is the strategy of speaking pleasantly with positive politeness. Furthermore, the advertisement discourse in Sindo newspaper uses the context of SPEAKING, but not all of it exists because advertisements take the form of written advertisements. The situation and place (setting and scene) cannot be determined because the ad is not an audio-visual ad that can be seen from the situation and place where the ad is displayed. The psychological situation of speech cannot be seen because advertisements are in written language, the psychological situation of ad speakers is not visible.
\end{abstract}

Keywords: illocutionary speech act, speech strategy, context, advertising language, Sindo newspaper

\section{INTRODUCTION}

Language is the main medium in communicating. Through language, a person can convey his desires, opinions, or his heart's content to others. As social beings, humans certainly communicate with other humans. Humans communicate to achieve their goals and to meet their needs, humans cannot be separated from dealing with other humans. To achieve these things humans need communication media.

One of the media that uses language is mass media. The development of mass media was marked by the birth of electronic media. In essence, traditional mass media are printed media, such as newspapers. Then, along with the times and technology, now there are electronic media, such as radio and television. Language plays an important role in the mass media to convey information. Also, the language in the mass media is often referred to as journalistic language.

Currently, the print media is not only a means of conveying information but also contains advertisements. Advertising is one of the most effective communication media to be used as a means of connecting producers and consumers. Advertising language must be able to be a manifestation or presentation of things whose purpose is to influence the public to be interested in something being advertised [1]. Manufacturers often use advertising as a tool to offer or promote their products. Therefore, all companies that produce new products, compete in placing advertisements as attractive as possible to get the maximum profit from the sales of advertised products. Through advertising, companies can create long-term beneficial interactions between the company and consumers. With companies carrying out advertising activities, it is hoped that they will be able to build a company image in the long term [2].

Advertising language predominantly uses words that mean seduction, suggestion, or invitation that can arouse curiosity. Advertisements are expected to provide information and instructions about a good or service. Consumers as potential buyers can find out the characteristics of goods or services after enjoying advertisements. Ads must be made as attractive as possible to attract potential buyers. Tomagola in [3] says that the ad maker has several goals in designing each ad. These objectives are (1) attracting attention, (2) arousing interest in reading or listening to advertisements, (3) stimulating curiosity, (4) creating beliefs about goods or services, and (5) generating the act of buying and using goods or services.

Research relevant to this research has existed before. One of them is Wafratur's research [4] which states that the form of localized acts found in beauty product advertisements on television is in the form of declarative sentences, interrogative sentences, and imperative 
sentences. In beauty product advertisements on television, the form of localized acts shows the dominance of the declarative sentence form. This shows that something is being reported to viewers who are watching the content and properties of the beauty products being advertised [2], [4], [5]. Also, the research by Ananda, Sutama, and Nurjaya [6] also shows that of the 20 advertisement slogans studied, 18 slogans contain indirect declarative speech acts and 2 slogans contain imperative speech acts. Meanwhile, one type of print media that contains advertisements is Sindo newspaper. Sindo newspaper is one of the biggest national newspapers in Indonesia which is published every day. First launched in 2005 under the name Seputar Indonesia. Sindo newspaper is a progressive newspaper aimed at a dynamic segment. Sindo newspaper features several interesting sections such as News, Economy, Business, Sports, Lifestyle, and Referensia. The language in Sindo newspaper advertisements can convey information effectively and efficiently through images and text. As displayed in Sindo newspaper, a large image size is used if the ad is displayed together with the news column. Apart from the news section, Koran Sindo also displays 2 full-page advertisements in a special column with the name information.

The language aspect studied in Sindo newspaper is illocutionary speech acts. In advertisements, ad speakers use verbs to announce, suggest, thank, promise, urge, force, propose, speculate, give advice, ask, order, command, order, invite, praise, criticize, flatter, say thank you, and forbid. These verbs are verbs that are found in illocutionary speech acts. The illocutionary speech act is a speech act that functions to say or inform something, it can also be used to do something [7]. In this case, ad speakers provide information about something and then invite their readers, both implicitly and explicitly, to buy the products offered and use the services that are informed.

This study aims to describe (1) the types of illocutionary speech acts used in the advertisement discourse in Sindo newspaper; (2) the story strategy contained in the advertisement discourse in Sindo newspaper; (3) the background context, participants, objectives, action sequences, keys, tools, norms, types in the use of illocutionary speech acts contained in the advertisement discourse in Sindo newspaper.

\section{METHOD}

This research is qualitative research with a descriptive design. The data source in this research is the advertisement discourse in Sindo newspaper published from 1 to 30 June 2015. The selection of data sources in June 2015 is based on the assumption that in that month the frequency of the advertisement discourse in Sindo newspaper is very high because it coincides with the fasting season until the holidays and new school year so that advertisers advertise more of their products that month.

Furthermore, the data in this study are illocutionary speech acts in the advertisement discourse in
Sindo newspaper which are grouped based on the type, strategy, and context of the speech act. The descriptive method is a research method by describing or describing the state of a phenomenon, subject, or object of research based on facts as it is and producing data in the form of written or spoken words from people and observed behavior [8].

The main research instrument is the researcher himself. Of course, researchers are equipped with knowledge and theories related to this topic. This is consistent with what Moleong [9] said that the instrument in qualitative research is that the researcher himself is assisted by other data collection tools.

According to Bogdan and Biglen in [9], data analysis is an effort made by working with data, organizing data, sorting it into manageable units, the sizing thesis, looking for and finding patterns, finding what is important and what to learn, and decide what to tell others.

Thus in this section data collection activities are carried out using the following steps. First, collecting all advertising documentation in June 2015 contained in the advertisement discourse in Sindo newspaper. Second, recording all the utterances contained in the advertisement discourse in Sindo newspaper. Third, identify the types of illocutionary speech acts used in the advertisement discourse in Sindo newspaper. Fourth, classifying all data in tabular form according to research objectives. Fifth, interpreting the data by looking at the relationship between the types of illocutionary speech acts used in the advertisement discourse in Sindo newspaper, the telling strategy contained in the advertisement discourse in Sindo newspaper, the context of using illocutionary speech acts contained in the advertisement discourse in Sindo newspaper and interpreting each of these relationships. Sixth, discuss and conclude the findings.

\section{RESULT AND DISCUSSION}

\subsection{Result}

\subsubsection{Types of illocutionary acts in the advertisement discourse in Sindo newspaper}

This section contains a description of the research findings on the types of illocutionary speech acts in the advertisement discourse in Sindo newspaper. For more details, see the table below.

Table 1. Types of the illocutionary speech act in the advertisement discourse in Sindo newspaper

\begin{tabular}{|llll|}
\hline No. & $\begin{array}{c}\text { Types of Illocutionary } \\
\text { Speech Acts }\end{array}$ & Total & Percentage \\
\hline 1. & Representative & 40 & $23.5 \%$ \\
\hline 2. & Directive & 80 & $47.0 \%$ \\
\hline 3. & Expressive & 17 & $10 \%$ \\
\hline 4. & Commissive & 27 & $15.8 \%$ \\
\hline 5. & Declaration & 6 & $3.52 \%$ \\
\hline Total & 170 & $100 \%$ \\
\hline
\end{tabular}


Some representative forms of the types of illocutionary speech act found in this study will be discussed as follows.

Types of representative illocutionary speech acts:

(1) "Bantex Home-Filling Products provides you with the best design, strength, durability, and quality assurance in your various personal document filing needs" (S6: 13/6/15)

The advertisement was delivered by Bantex. Speakers, namely the Bantex party, stated that the Bantex Home Filling Product provides the best service to readers as speech partners, be it services in terms of design, strength, and quality assurance of document archiving, everything provided is the best service. The entire quotation from the representative speech act sentence above proves that the said speech act is of the stated type.

Types of directive illocutionary speech acts:

(2) "Let's use the Rupiah, safeguard the sovereignty of the Republic of Indonesia, maintain the stability of the Indonesian economy!"

(S: 155: 30/6/2015)

The advertisement was submitted by Bank Indonesia. Speakers, namely Bank Indonesia invite readers as speech partners to use the rupiah currency more in transactions because the rupiah currency is a symbol of the sovereignty of the Republic of Indonesia and maintains the stability of the rupiah against foreign currencies. Speech that contains a directive type of speech act invites, namely the word come. Come on, the goal is to invite.

Types of expressive illocutionary speech acts:

(3) There is no room for error

$$
\text { (S: 53: 7/6/2015) }
$$

The advertisement was delivered by the Indonesian Master Chef. Speakers, namely the Indonesian Master Chef criticize readers as speech partners who want to participate in the Indonesian Master Chef competition, that they should not make the slightest mistake when competing because the slightest mistake cannot be tolerated. The whole sentences of the expressive speech act above prove that the speech act is of a critical type

Types of commissive illocutionary speech acts:

(4) "A definite solution for those of you who want to look slim, sexy, charming and youthful obesity free for men and women. $100 \%$ safe herbal ingredients."

$$
\text { (S: 24: 3/6/2015) }
$$

The advertisement was delivered by NY Potions. Ulfa Hasan. The speakers are NY Potions. Ulfa Hasan promises to readers as a speech partner who has bought the medicine that the drug can provide a solution for those who want to appear slim and free from obesity. The word solution proves that the speech act is included in the promise-type commissive speech act.

Types of declaration illocutionary speech acts:

(5) "Top Coffee.. the Coffee is Indonesian people"

(S: 23: 3/6/2015)

The advertisement was delivered by Top Coffee. Speakers, namely the Top Coffee party, told the reader as a speech partner that Top Coffee is Indonesian coffee. The coffee is Indonesian, which means Top Coffee, the coffee is classified as Indonesian. The entire sentence above proves that the said speech act contains classifying type declaration speech acts.

\subsubsection{Types of illocutionary acts in the advertisement discourse in Sindo newspaper}

This section contains a description of the research findings on the types of illocutionary speech acts in the advertisement discourse in Sindo newspaper. For more details, see the table below.

Table 2. Strategies to talk about illocution in the advertisement discourse in Sindo newspaper

\begin{tabular}{|llll|}
\hline No. & $\begin{array}{l}\text { Illocutionary Strategies } \\
\text { Speak frankly without } \\
\text { further ado }\end{array}$ & 67 & $39.4 \%$ \\
\hline 2. & Speak positive courtesy & 75 & $44.1 \%$ \\
\hline 3. & $\begin{array}{l}\text { Small talk } \\
\text { negative politeness }\end{array}$ & 17 & $10 \%$ \\
\hline 4. & Speaking vaguely & 11 & $6.47 \%$ \\
\hline 5. & Speak to yourself & 0 & $0 \%$ \\
\hline Total & 170 & $100 \%$ \\
\hline
\end{tabular}

Some representative forms of illocutionary storytelling strategies found in this study will be discussed as follows.

Strategy straightforwardly without further ado:

(6) "Get The Movie Kids from The Star Children's DVD at KFC Stores throughout Indonesia."

(S: 29: 3/6/2015)

The advertisement was delivered by KFC. Speakers, namely the KFC, speak frankly without further ado telling readers as speech partners if you want to get DVDs you can buy them at KFC Stores throughout Indonesia. The entire sentence above proves that the speech act contains a strategy to speak frankly without further ado.

Positive polite politeness strategy:

(7) "Sure solution goes $(100 \%$ money back Haij / Umrah!"

(S: 25: 3/6/2015) 
The advertisement was delivered by the Haj and Umrah Travel Bureau. Speakers, namely the Haj and Umrah Travel Bureau promised readers as speech partners who wish to register at the Haj and Umrah Travel Bureau that those who have registered will be certain to leave for Haj and Umrah. If canceled then all money back 100\%. The speaker builds a positive image for the speech partner, namely readers with a guarantee of money back, leaving for Hajj or Umrah is canceled. The entire sentence above proves that the speech act contains a strategy of speaking positive politeness by using the promising speech strategy.

\section{Negative politeness strategy:}

(8) "Do you want to have business software tour \& travel?"

(S: 12: 6/1/2015)

The advertisement was delivered by the tour \& travel agency. Speakers, namely the Tour \& Travel agency, provide a request in the form of a question to readers as a speech partner to join their Tour \& Travel agency business because to have the software the said partner must join them. Speakers who were initially afraid to join were offered a bonus to the Tour \& Travel agency business software to ensure that the Tour \& Travel agency business was very profitable so that the negative image in the speaker's mind turned into a positive image. The entire sentence above proves that the speech act contains a strategy of speaking negative politeness by using a speech strategy using a strategy of speaking requests in the form of a question

A strategy is cryptic:

(74) "A drop of blood that you give is like a drop of living water to those in need."

Valencia Mieke Randa

(Social Activist).

(S: 42: 5/62015)

Vague speech containing strong gestures is a speech with a strong focus. The ad was delivered by Tupperware She Can. Speakers, namely Tupperware, invite said partners to become blood donors. The speaker quoted the words of social activists to encourage readers, namely speech partners, to donate blood because donating blood can save the life of someone who is critical and needs a lot of blood. The entire sentence above proves that the speech act contains a vague speech strategy using a speech strategy that contains strong signals.

\subsubsection{Context of Background and Situation, Participants, Objectives, Sequences of Actions, Keys, Tools, Norms, Types in the advertisement discourse in Sindo newspaper}

The data in the advertising discourse on the daily newspaper Koran Sindo is as much as 110 advertising discourse data. Overall data has the context to find out the meaning contained in the advertising discourse. The context component in communication is known as SPEAKING. Setting and scene concerning time, place situation, and psychological situation of speech. Participants are the parties involved in the speech event. Ends are the intention and purpose of the speaker. An action sequence is a form of speech and the content of the speech topic, the form of the speech is related to the words used, and the topic of the conversation. Keys refer to the tone and way the speaker delivers the message. Instrumentalities are the language path used by speakers, spoken or written language pathways. The norm of interaction and interpretation refers to the norms of the rules for interaction. Genre refers to the type of presentation such as narration, poetry, proverbs, prayers, proverbs, puzzles, and others. Research findings for the SPEAKING context are described in general terms and some are described specifically. The general context of SPEAKING is described in the following sections.

\section{Setting and Scene}

In the discourse of advertising on the daily newspaper Koran Sindo use the SPEAKING context, but not all research findings are in the whole SPEAKING context because advertisements are in the form of written advertisements. The setting and scene cannot be determined because the ad is not an audio-visual ad that can be seen from the situation and place where the ad is displayed. The time in the daily newspaper Koran Sindo advertisement is the time the advertisement is printed. The psychological situation of speech cannot be seen because advertisements are in written language, the psychological situation of ad speakers is not visible.

\section{Participant}

Participants in the advertisement discourse in Sindo newspaper are advertisers as speakers and readers as speech partners. The advertiser conveys something to the speech partner through the language of the written advertisement, then the speech partner does what is asked by the speech partner if the said partner is interested in what the ad speaker offers.

\section{Ends}

Ends the advertisement discourse in Sindo newspaper are advertisers offering goods and services to speech partners, besides providing important information, namely public service advertisements, information about the admission of new students at private universities, thank you by the company to people who are considered to have 
congratulations addressed to readers as speech partners, advances in public service announcements.

\section{Act Sequence}

The act sequence is the advertisement discourse in Sindo newspaper the form of speech used is direct, directly to the intent and purpose that will be conveyed to the reader as a speech partner. The topics discussed were offering goods and services, providing information, saying congratulations, thanks, and advice for speech partners in public service announcements.

\section{Keys}

Keys in daily ads Koran Sindo the speaker conveys what he says in short, serious language when offering products and services, information, thanks, congratulations. The language is short and not long so that what is conveyed by the speaker goes directly to the goal, namely inviting the speech partner to do something according to the speaker's wish.

\section{Instrumentalities}

Instrumentalities on the daily newspaper Koran Sindo advertisements the way speakers convey messages on the daily newspaper Koran Sindo advertisements is in writing. The message conveyed is made as attractive as possible with a combination of pictures and writing so that what is conveyed by the speaker is easily understood by the speech partner, namely the reader. Through pictures, readers as speech partners can understand because images can represent the words conveyed.

\section{Norm of Interaction and Interpretation}

Interaction norms and Norm of interaction and interpretation in the daily advertisement of Koran Sindo speakers, advertisers are more proud to think that their products are the best and the best. The sentence that is conveyed is boasting of the product by explaining the advantages of the product being offered and considering the product they offer is the best. Speakers pride themselves in writing advertisements so that speech partners or readers have more confidence in the quality of the goods and services offered by advertisers so that readers' interest in the products offered is greater.

\section{Genre}

A genre of written language advertising speech on the daily newspaper Koran Sindo advertisements is written exposition. Speakers explain ideas, ideas, explain what they are conveying to the speech partners as readers with a short, accurate, and concise writing style. The things given are information on the products and services offered, important information conveyed to speech partners, congratulations and thanks, the advice in public service announcements.

The following is an analysis of context specifically in the Discourse on Advertising in Koran Sindo's the daily newspaper:
(9) "Pertamax \& Fastron go to Europe. Buy Pertamax (IDR 200,000 / car, IDR 20,000 / motorcycle) \& Fastron (4 liters). Please visit www.pertaminapfgte.com.

Win 10 Eurotrips to watch F1 \& GP2 live in Monza and travel to Barcelona!

21 goldbars@5gram

24 Samsung Galaxy Note 4

9 IPHONE $616 \mathrm{~GB}$

24 BBK Voucher@RP. 1,000,000,000

60 Fastron@4liters

Period: 1 May-10 August 2015

\section{(S: $1: 6 / 1 / 2015)$}

\section{*) Terms and Conditions apply"}

This advertisement was published on Monday 1 June 2015 by Pertamina. This advertisement states about Pertamax \& Fastron information. This advertisement uses written language that is direct and aims to promise and challenge customers to buy Pertamax and be accompanied by prizes to go to Europe.

\subsection{Discussion}

Advertising generally invites buyers to do something when buyers offer goods and services to consumers. Doing something is buying goods and services advertised by advertisers. Besides, advertisements contain information to listeners and readers, such information can be in the form of job vacancies information, educational information in the form of student and new student admissions, scholarship information, information about events held by advertisers, information about public service advertisements in the form of appeals, and advice.

Advertising language in newspapers is made as good and attractive as possible with language that is easy to understand so that the speech spoken by the advertisement writer can be understood easily by the reader so that the intent and purpose of the advertisement are quickly understood by the reader (speech partner). This is by following under the results of research by Rahmi [10] which concluded that diction with the right criteria for the concept, the right value of taste in advertisements has a connotative / directive / persuasive function, the language style of advertising refers to the poetic function of language which aims to create a beautiful effect in advertising language. Also, images in advertisements have three functions to convey messages, namely icons, indexes, and symbols [10]. One of the advertising languages that the researcher examined was "Illocutionary Speech Act in The Discourse Advertisement on The Daily Newspaper Koran Sindo."

The first thing to be examined in this study is the type of illocutionary speech act that is contained in the advertising discourse on the daily newspaper Koran Sindo. First, the type of speech act that is most dominant in the discourse of advertisements on the daily newspaper Koran Sindo is the directive speech act with a total of 80 utterances. Second, 
there were 40 representative speech acts. Third, there were 27 commissive speech acts. Fourth, expressive speech acts totaling 17 utterances. Fifth, there are 6 speech acts in the declaration.

This is by following the opinion of Antarikso [11] who states that the advertising language must be presented in a language that is easily understood by the target audience. Based on the results of research, the dominance of directive speech acts is because, in the discourse of advertisements on the daily newspaper Koran Sindo, the ad speakers tell more readers (speech partners) to do something, namely to buy goods and services offered by the speakers. More speakers tell speech partners to buy the products they advertise because in advertising the main purpose of advertising is to get buyers to buy the products offered in the advertisement.

Also, the least amount of declaration speech acts because speakers do not use many sentences to valid, decide, canceling, prohibiting, permitting, granting, lifting when telling the speech they convey to the speech partner. All kinds of speech acts in the declaration are very rarely found in advertising discourse on the daily newspaper Koran Sindo.

The second thing that was examined was the strategy of telling the advertising discourse on the daily newspaper Koran Sindo. A strategy is a method used by speakers so that what they say is understood by the speech partner so that the speech partner is interested in doing what the speaker wants. Without a strategy, it is very difficult for the goods and services to be promoted to attract the attention of the speech partners because that strategy makes the objectives to be conveyed quickly understood by the speech partners who are expected to become consumers. This is by following under the opinion of Agustrijanto [12] who explains that advertisements made must be able to realize the reader's interest in buyer behavior, namely in the form of the words used must be urgent; draw attention; able to build a positive image.

The most dominant strategy in advertising discourse on the daily newspaper Koran Sindo is the strategy of speaking positive politeness in as many as 75 stories. Then, the strategy was to speak frankly without further ado as many as 67 speeches. Furthermore, the strategy of speaking negative politeness was 17 . Finally, the strategy is to speak obscurely as many as 11 stories. This confirms that there is not a single story that uses the strategy of speaking inwardly in the advertising discourse on the daily newspaper Koran Sindo. This is by following the opinion of Syahrul [13] who explains that the basis for choosing a speech strategy is the factors of social distance between speakers and speech partners, differences in power between speakers and speech partners, and the threat of a speech act based on certain cultural views.

Speaking using positive politeness is aimed at the positive face of the speech partner, namely the positive image that is considered the speech partner while speaking with negative politeness is aimed at how to fulfill or save part of the negative face of the interlocutor. Furthermore, speaking vaguely is done if the speaker wants to do facethreatening actions, but the speaker does not want to be responsible for the action while speaking in the heart of the speaker does not express his intentions. Besides, speakers prefer to be silent and only keep their speech in their hearts because speakers want to avoid hurting speakers through speech that may potentially threaten the speaker's face [13].

The dominance of the strategy of speaking positive politeness in the advertising discourse on the daily newspaper Koran Sindo is because more speakers promise that the product is the best, very good, and quality. In the strategy of speaking positive politeness, one of the strategies is promising speech. Speakers promised more things to the speech partners, be it in the form of discounts, low prices, good quality goods, attractive prizes. Another strategy is for speakers to involve speech partners in one activity. With this involvement, familiarity will be established between speakers and speech partners so that the speech partners become regular customers to buy products advertised by speakers. This is by following the opinion of Chandra [14] who states that the objectives of advertising include: (1) create awareness of brand names, product concepts, or information about where and how to buy products; (2) remind buyers to use or buy the product again; and (3) changing attitudes towards product use

Another strategy is that the speech is optimistic to the speech partners, without being optimistic and assuming that the products offered by speakers are the best, affordable prices, lots of attractive discounts and attractive prizes offered, so the speech partners are less interested in the products offered by the speakers. The dominance of the positive polite speech strategy used by speakers is one of the ways that speakers do so that what they convey in the advertisement achieves its goals and objectives for the speech partners, namely readers. There are five communication functions, namely providing information, persuading, reminding, adding value, and accompanying [15].

The third thing the researchers examined was the context in which illocutionary speech acts were used in the advertising discourse on the daily newspaper Koran Sindo. To determine the intent and purpose of a speech, the context must be known. If the context of the sentence is unknown, it is very difficult to determine the meaning and purpose of the sentence. 8 things that must be known in a speech sentence, namely SPEAKING. Setting and scene, Ends, act sequence, keys, instrumentalities, Norm of interaction and interpretation, genre. This is by following the opinion of Chandra [14]) who states that advertisers must be able to change their perceptions of the importance of brand attributes, change beliefs in brands,

In general, the SPEAKING context is found in illocutionary speech acts contained in the advertising discourse on the daily newspaper Koran Sindo. The first context is the situation and place. The context of the situation and place is not found, only parts of the situation and place are found because the advertising language in print media is written and does not take the form of twoway dialogue, spoken sentences are only one-way sentences. The situation when the speech is delivered is not visible because the situation is represented only by 
pictures and writing. Likewise, the place and the place cannot be known because the language of advertisements in the print media, emphasizes speech, in contrast to advertisements in electronic media where it is directly videotaped and the speech is spoken in that place. If the advertisement is in print media, it is not clear where to tell. Even though the location is drawn, it is only the location where the product is sold, not the location where the speaker writes the ad. Psychology cannot also be determined because the expressions on the faces and expressions of the speakers cannot be seen when delivering advertisements. After all, advertisements are written in writing. This context can be used to see the cohesion relationship in a speech/sentence.

In terms of discourse, determining the meaning of a speech/sentence depends on the context of the discourse as the environment in which the speech/sentence is located. The cohesion relationship between ideas in one discourse can be seen using the context of discourse [16]. The context of the situation and place can only be determined when the advertisement was published in electronic media. The second context is the participants. In the illocutionary speech act in the advertising discourse on the daily newspaper Koran Sindo, it is clear that the participants are advertisers and readers. Advertisers as speakers and readers as speech partners who will do something the speakers ask for. The third context is the goal. The purpose of the advertising discourse on the daily newspaper Koran Sindo is to offer goods and services to consumers, provide information, express gratitude, congratulate, and advise on public service announcements. The fourth context is the sequence of actions. The sequence of actions is a form of speech used by speakers. This is following under the opinion of Koesworo [17] that (1) the language of advertising provides uniqueness in the form of simple, short, concise, clear, direct sentences; (2) lively following under the era, contains a wealth of language; (3) short sentences and positive words, containing lots of facts, and using as few words as possible; and pay attention to grammar.

The form of speech used is direct speech on the intent and purpose of the speech. The fifth context is key, such as advertisements in electronic media no later than 60 seconds, advertisements in the discourse of Koran Sindo speech act daily advertisements which are delivered in short, serious and direct language to the intent and purpose of the advertisement being conveyed to readers, namely the speech partners. The sixth context is tools. Tools are a way for speakers to convey messages. Ad speakers convey a written message with a blend of images. The seventh context is the norm of interaction and norms of interpretation. More speakers think that their product is the best and seem to boast that the product is the best, the best. The eighth context type, the type of language used in the advertising language in the advertising discourse on the daily newspaper Koran Sindo is exposition. Exposition with a short writing style, accurate and concise. Also, the structure of the word chart in advertisements must be evocative, informative, persuasive, powerful in motion, and have a final solution [12].

\section{CONCLUSION}

Based on the research results, it can be concluded that the following matters. First, the dominant illocutionary speech act found in advertising discourse on the daily newspaper Koran Sindo is directive speech acts. Also, directive speech acts were found in the form of challenging statements, ordering, inviting, asking, suggesting, ordering, pressing, proposing, compelling, and pleading. Second, the dominant narrative strategy in the advertising discourse on the daily newspaper Koran Sindo is the strategy of speaking pleasantly with positive politeness, such as: promising, involving speakers and speech partners in one activity, being optimistic about speech partners, multiplying sympathy for speech partners, using identity markers as members of the same group, seek agreement, provide reasons, and claim mutual assistance. Besides, there is no internal speech strategy because the language of written spoken advertising is direct. Third, in the advertising discourse on the daily newspaper Koran Sindo uses the context of SPEAKING, but not all of it exists because advertisements are in the form of written advertisements. Setting and scene cannot be determined because the ad is not an audio-visual ad that can be seen from the situation and place where the ad is displayed. The psychological situation of speech cannot be seen because advertisements are in written language, the psychological situation of ad speakers is not visible.

\section{ACKNOWLEDGMENT}

Finally, this paper finished with the support of everyone who follows me. This paper is far from perfect, but it is expected that it will be useful not only for the researcher but also for the readers. For this reason, constructive thoughtful suggestions and critics are welcomed. Thank you.

\section{REFERENCES}

[1] N. F. Hermawan, "Bahasa dalam iklan layanan masyarakat," El-Wasathiya J. Stud. Agama, vol. 2, no. 1, pp. 71-83, 2016.

[2] W. Nasution and Efrima, "Analisis tindak tutur ilokusi dalam iklan radio 99,3 Toss FM Merduati Banda Aceh," J. Metamorf., vol. 7, no. 2, pp. 269-283, 2019.

[3] S. P. Astuti, "Fungsi bahasa dalam wacana iklan media cetak," Nusa J. Ilmu Bhs. dan Sastra, vol. 3, no. 1, pp. 1-18, 2012.

[4] Wafratur, "Analisis tindak tutur dalam iklan produk kecantikan di televisi," J. Bhs. dan Sastra Indones., vol. 6, no. 1, pp. 75-84, 2017.

[5] A. P. Wulan, "Analisis tindak tutur dalam iklan motor dan mobil dalam harian umum Sloops," vol. 2, no. 2, pp. 149-164, 2013.

[6] N. Avidia Ananda, I. M. Sutama, and I. G. 
Nurjaya, "Bentuk dan fungsi tindak tutur slogan varian iklan Pond's di televisi swasta," $E$ Journal JJPBS, vol. 3, no. 1, pp. 1-12, 2015.

[7] I. D. P. Wijana, Dasar-dasar pragmatik. Yogyakarta: Andi Offset, 1996.

[8] Sugiyono, Metode penelitian pendidikan pendekatan kuantitatif, kualitatif dan $R \& D$. Bandung: Alfabeta, 2014.

[9] L. J. Moleong, "Metodologi penelitian kualitatif (Edisi revisi)," Bandung: Remaja Rosdakarya, 2017.

[10] A. Rahmi, "Pengungkapan pesan teks iklan produk otomotif di media cetak kota Padang," Padang: Universitas Negeri Padang, 2011.

[11] S. Antarikso, Etika pariwara Indonesia: Amandemen 2014. Jakarta: Dewan Perikanan Indonesia, 2014.

[12] Agustrijanto, Copywriting: Seni mengasah kreativitas dan memahami bahasa iklan. Bandung: Remaja Rosdakarya, 2012.

[13] S. Ramadhan, Pragmatik kesantunan berbahasa. Padang: UNP Press, 2008.

[14] G. Chandra, Strategi dan program pemasaran. Yogyakarta: Andi Offset, 2002.

[15] Shimp, Perikanan Promosi (Aspek Tambahan Komunikasi Pemasaran Terpadu). 2007.

[16] A. Yasin, Tindak tutur: Sebuah gramatika komunikatif. Padang: Sukabina Offset, 2008.

[17] F. X. Koesworo, J. B. Margantoro, and R. S. Viko, Di balik tugas kuli-tinta. Surakarta: Sebelas Maret University Press, 1994. 